\title{
Mahathir's Leadership Post-general Election 14: Perspectives of the Malay Community in West Malaysia
}

\author{
SHAUQAT ADAM SHAMSUL JIHAR
}

\author{
Faculty of Social Science and Humanities, Universiti Malaysia Sarawak, 94300 Kota Samarahan, Sarawak, \\ Malaysia \\ *Corresponding author: shauqatadam@gmail.com
}

\begin{abstract}
New history is created in Malaysia. After over six decades of Federal rule, the Barisan Nasional (BN) government has been replaced by a coalition of opposition parties, the Pakatan Harapan $(\mathrm{PH})$ in the most recent general election. PH also managed to form several state governments traditionally held by BN in Peninsular Malaysia. This study aims to seek the perception of the Malays in West Malaysia in accepting the return of Tun Dr. Mahathir Mohamad into power. It focuses on the so-called political comeback of Tun Dr. Mahathir Mohamad - the first leader to be appointed Prime Minister twice considering this rarely happens in Malaysia. This study was conducted in West Malaysia involving eighty-eight respondents using the 5-point Likert-scale survey questionnaire. Respondents were given an option to answer the questionnaire in Bahasa Malaysia or English. The general result showed that perception towards political issues in Malaysia, especially with regard to Tun Dr. Mahathir Mohamad's comeback drew mixed reactions. On the same note, it showed that people could have lost their hopes and direction of Malaysian politics.
\end{abstract}

Keywords: Barisan Nasional, Dr. Mahathir, General Election 2018, Pakatan Harapan, political comeback.

Copyright: This is an open access article distributed under the terms of the CC-BY-NC-SA (Creative Commons Attribution-NonCommercial-Share Alike 4.0 International License) which permits unrestricted use, distribution, and reproduction in any medium, for non-commercial purposes, provided the original work of the author(s) is properly cited.

\section{INTRODUCTION}

The 2018 general election has changed the Malaysian political landscape (Mohamed Noor, 2018). Scholars have offered various speculations in explaining the impact of the $14^{\text {th }}$ General Election on Malaysian politics. Many consider this to be a new political phenomenon in Malaysia. It is deemed unique when old political features such as hegemonic politics, racial, developmental politics, and so forth practised by a coalition of major ethnic parties in the United Malays National Organisation-led Barisan National (BN) party have begun to decline and have been abandoned (Moniruzzaman \& Farzana, 2018). These new political features are slowly eroding the old political practices, which were nurtured by the ruling party in maintaining power. BN's dominance in Malaysian politics has always been closely linked to the rules of racial politics, unity, break and order, control, and development (Mohamed, 2008).

Within this notion also, many expected the regime of $\mathrm{BN}$ to win comfortably, especially when the then opposition coalition was in trouble (Washida, 2018). The dissolution of the opposition party led to a threepronged rivalry that would typically benefit the ruling party. At the same time, some of the critical and controversial issues of the Najib Razak administration began to settle, particularly the 1Malaysia Development Berhad (1MDB) embezzlement, the RM2.6 billion deposit in Najib's account, and the introduction of a new tax system of Goods and Services Tax (GST) (Mohamed Noor \& Jamaie, 2018).

Tun Dr. Mahathir Mohamad is the longest-serving prime minister in Malaysia's political history. His prior terms were from 1981 to 2003 and he was also a seasoned world administrative leader. Before establishing the new party of BERSATU (Malaysian United Indigenous Party), instituted under the formation of an official coalition with the Pakatan Harapan (PH), he was the BN leader throughout his service, the top administrator, primarily during the millennial years (Besar, 2019). 
The main objective of this study is to determine the level of acceptance of Tun Dr. Mahathir Mohamad's return into Malaysia's political scene amongst the Malays. As the re-emergence of power is seldom to happen in world politics, especially Malaysia, hence this study is significant as part of a 'New Malaysia' narrative post-BN federal ruling after so many years.

\section{METHODOLOGY}

This research was conducted to measure the acceptance of Tun Dr. Mahathir Mohamad's comeback into the political arena. This study mainly focused on the Malays that make up $63.1 \%$ of the total population in the country. Using descriptive method, the research problem was structured around understanding the perception of people of an overwhelmingly popular leader. Descriptive characteristics made up most of the feedback. The main idea behind using this type of research was to define better the opinions, attitudes, and behaviours held by a group of people on the issue. This enabled the researcher to gauge the importance of decisions from the study population and their opinions, attitudes, and behaviours based on a particular period in the political history of Malaysia.

From the survey, 50 male respondents $(56.8 \%)$ and 38 female respondents $(43.2 \%)$ were involved, whose ages ranged from 21 to 60 years old. In accordance with the initial methodology plan, the study was expected to involve 200 respondents across West Malaysia, but the COVID-19 pandemic and the subsequent implementation of Movement Control Order (MCO) by the government that lasted for months derailed the conduct of this research. Instead of going around meeting potential respondents, the researcher transitioned to using online Google form survey. The age range is to ensure a substantial amount of understanding of the respondents in regard to the issues raised in this survey, which mainly revolved around politics and history. From the total number of respondents, $31.8 \%$ worked in the private sector, while $28.4 \%$ were students in higher institution of learning. This study also managed to obtain a total view on the political issues circulating around the administration of $\mathrm{PH}$ as the former government of Malaysia, in which $53.4 \%$ respondents involved reside in urban areas while the rest from rural and semi-urban areas. As different political issues and values stand varyingly in accordance to the background of respondents, this study could have variant perspectives on Malaysia's politics including the administration, economic concerns, social welfare, nation development, racial polarization and many more.

The survey was structured around issues and values on the leadership of Tun Dr. Mahathir Mohamad in PH. It also contained respondents' background, approval on Tun Dr. Mahathir Mohamad's leadership, perception on direction under PH's administration, perception on current issues and concerns, perception on social impacts that mainly revolved around Tun Dr. Mahathir Mohamad's leadership in BN, and general views of respondents towards both PH and BN governments. As the questions focused on respondents' perception, this was to explore their acceptance of the reemergence of Tun Dr. Mahathir Mohamad into power by differentiating his leadership during his term in BN and in PH. A simple encoding using the SPPS software was utilized.

\section{ANALYSIS}

From the study findings, most respondents showed a mixed response regarding their approval of Tun Dr. Mahathir Mohamad's leadership in the PH government. Some of the features of his leadership were perceived positively. However, there were still different factors that received opposing views including on their perceptions on the management of the PH government, which was viewed negatively. This can be concluded that most respondents were still in their process of assessing and approving the political conduct of both Tun Dr. Mahathir Mohamad and his administration since they only had a short time to execute all their promises and job scopes.

\section{Differences on social well-being of Malays during the Mahathir years in BN and PH}

In discussing the perspective of the respondents regarding their acceptance of Tun Dr. Mahathir Mohamad's political comeback, the researcher needed to explore the differences on the social well-being of the Malays during the reigns of both leadership (BN and $\mathrm{PH}$ ). In general, there is a significant difference between these two periods, considering that his governing period as the fourth Prime Minister (PM) was longer than the recent one, hence many actions and policies could be implemented and executed. Undeniably, there were many changes and reforms he had done to Malaysia as the fourth PM. One of the prominent contributions was the initiation of mega 
development projects. With his idea, Malaysia's stateliest high-rise structure, the Kuala Lumpur City Centre (KLCC), was built. With the inspiration of Islamic motives, not only the KLCC had been the tallest building in the world once, but this structure had also set Malaysia notably in the map of the world. Not only that, other initiatives such as the privatization of Malaysia's public services had also transformed the economic scene and managed to deliver a good projection towards Malaysia's economy. Lembaga Letrik Negara was privatized during his reign in the BN government, and now called Tenaga Nasional and established as the largest electric utility company in the country.

The development initiatives of Tun Dr. Mahathir Mohamad and his administration during the BN regime received mixed reactions from the respondents considering that majority of the respondents once witnessed Tun Dr. Mahathir Mohamad's earlier leadership. Even then, not much can be drawn from the other group of respondents namely those who have not observed his premiership the first time. Interestingly, the respondents believed that Tun Dr. Mahathir Mohamad's policies during his first reign as PM seemed to provide benefits to them although some chose to remain undecided (neutral) on this question.

With this specific research question of "What is the difference in terms of the social well-being of the Malays during the period of Tun Dr. Mahathir Mohamad in BN and PH?", the respondents have been sought to respond with two categories of related questions that revolved around the policies implemented by Tun Dr. Mahathir Mohamad and other general initiatives brought by him. For those who viewed the positive contributions, Tun Dr Mahathir Mohamad's implementation of the Look-East Policy received a high point saying that it was a good policy that his administration has implemented.

Though some other policies and acts have received nationwide criticisms such as the implementation of the Sedition Act 1948, still, the respondents viewed this act positively. They even disagreed with the abolishment of this act. This could be depicted that despite having to be deemed negative, the Malays of West Malaysia seemed to favour these actions as these will not only protect their rights as Malaysians but also create a balanced and harmonious community within the various ethnicities of Malaysia.

Apart from the policies implemented during the BN administration, the development initiatives brought by Tun Dr. Mahathir Mohamad's leadership also was well received by these individuals. The initiatives and actions have been long established hence the impacts and benefits were visible. These development initiatives served not only great impact to Malaysia but also for other countries to benefit from it, such as the initiative of establishing International Islamic University Malaysia, as an international institution of Islamic education in the region. This institution has produced thousands of graduates not only from Malaysia but across the world. These development initiatives have not only improved the social well-being of Malaysians but also brought forward Malaysia's economy, and this could be seen during the 1997 Asian financial crisis in which Tun Dr. Mahathir Mohamad and his government managed to stabilize the nation against a potential major downfall.

While there were differences in opinion, but more dwell on the positive when assessing Tun Dr. Mahathir Mohamad's earlier government, his recent reign as PM under the PH government raised several concerns from across the political divide. The majority of the respondents were skeptical of him and his PH administration. The prominent sector that received major concerns was the economic sector in which every major issue such as inflation, national budget, deficit, and lack of job opportunities have received negative reactions. This could be considered due to the expectations set by Malaysians based on the promises outlined by the previous government, especially before the $14^{\text {th }}$ General Election. In addition, issues related to racial relations were also on the spotlight during the brief rule of PH. Despite of the Malay claim of prioritizing their special rights, they also felt that racial unity in Malaysia needs to be brought forward as a major concern. Disputes were everywhere throughout the less than two years of PH government in Malaysia. This could be proven through the question of, "In which administration do you think Tun Dr. Mahathir Mohamad worked well?", in which the majority with $85.2 \%$ chose BN and the remaining opted for PH (Table 1). 
From the data, most of the respondents viewed that the social well-being of Malaysians was taken care of better during Tun Dr. Mahathir Mohamad's first reign. Nevertheless, his brief rule under PH government needed to put into consideration as there were not many development initiatives implemented during this time.

Table 1. Distribution of Respondents based on 'In Which Administration did Tun Dr. Mahathir Mohamad Worked Well?’ question

\begin{tabular}{lcc}
\hline & Frequency & Percentage $(\%)$ \\
\hline Barisan Nasional & 75 & 85.2 \\
Pakatan Harapan & 13 & 14.8 \\
\hline Total & 88 & 100 \\
\hline
\end{tabular}

\section{The Malay perception of Tun Dr. Mahathir Mohamad post 14th General Election}

In terms of factors that contributed to the positive and negative directions in the management of the previous government, different levels of responses were received. The results showed that there was a significant difference on the overall perceptions of respondents on both directions. In comparison, despite having a substantial amount of respondents agreed on the factors that could contribute to the right direction that Malaysia was heading, still, a higher number of the respondents consistently agreed that factors including economic concerns, negative quality of leadership, political instability (in general), poor administration and racial polarization were heading Malaysia towards the opposite direction (wrong). Regardless of the time spent for PH governing the country, the data showed that respondents had skeptical views on the previous government.

Based on the questions on the Malays perception on Tun Dr. Mahathir Mohamad post 14th General Election in West Malaysia, respondents shared again that Malaysia was heading either way - the positive direction or the wrong direction. It will be a bit difficult to construct thorough judgments on his performance as the previous government had a short time to administer the country. This is where two sides of consideration were configured along with the questions directed to the respondents. Nevertheless, Tun Dr. Mahathir Mohamad received mixed reactions based on his previous administration, as many issues and concerns are being covered. At the moment, a lot is yet to be done to investigate the brief tenure of Tun Dr. Mahathir Mohamad as PM of $\mathrm{PH}$.

Based on the data conducted, the majority of the respondents perceived Tun Dr. Mahathir Mohamad and his administration negatively while considering the country was heading in the right direction. Issues concerning the economic sector, social welfare, and development of the nation were deemed to be a strong point for the previous government. Even though a high number of the respondents opted to be in the intermediate side as they chose to view these issues impartially, the issues the respondents disagreed were at par and even higher in certain sectors. The most obvious figures in the data were on the economic sector. Most of them disagreed on how our economy was run while considering that Malaysia was heading in the right direction. It should be noted that one of the reasons of BN's downfall in the 14th General Election was due to economic concerns and the prominent promises from the $\mathrm{PH}$ government prior to the election, which centered on the economy i.e. the abolition of GST. However, their performance during their time had disappointed the citizens, especially the Malays. Nonetheless, several aspects related to running an efficient administration were viewed positively. Respondents perceived the policies implemented, an efficient civil service, and experienced administration as their strong points in which they agreed these factors contributed to positive direction of the government. This could be due to the transition happening from the long-governed $\mathrm{BN}$ to the hopeful and reformed $\mathrm{PH}$. Malaysians might have felt a fresh start and had hoped that with this newly elected government, controversial issues faced by BN government such as corruption and the 1MDB case must be resolved soon.

In addition, more than half of the respondents agreed that economic issues such as unfavourable economic conditions, inflation, low wages, budget deficit, and the weakening of the Malaysia ringgit were some of the setbacks raised from the previous administration. To consider most of these issues, they did not directly serve as impacts from the PH government. These problems mainly came from the BN government. Issues such as weakening of the ringgit and low-income families have already been presented back then. However, as a new 
government, along with their promises, Malaysians were expecting that $\mathrm{PH}$ would initiate reforms by making the country great again - similar to the earlier premiership of Tun Dr. Mahathir Mohamad. With the seemingly excellent form of leadership in Tun Dr. Mahathir Mohamad, PH could have moved Malaysia forward. It somehow did not happen, and the people sorely missed needed it. In view of this, the respondents disagreed on their leadership performance where they perceived $\mathrm{PH}$ as politically unstable and failed to deliver their promises. In short, it can be deduced that the recent Tun Dr. Mahathir Mohamad administration was viewed negatively by the Malays.

\section{The relevance of Tun Dr. Mahathir Mohamad in today's political scene}

Tun Dr. Mahathir Mohamad is considered as a notable leader and politician of Malaysia. From his remarkable academic background of medicine to his outstanding contributions to Malaysia, undeniably, he is well respected not only in Malaysia but also all across the globe. His amazing leadership skills once again have been proven when he was appointed as the PM of Malaysia twice in the history of the country. However, despite having noble achievements, he was still criticized and looked down, especially during his latest Prime Ministership in PH.

Based on the results, majority of the respondents either approved or undecided in the way Tun Dr. Mahathir Mohamad handled his job in PH. While it may be true Tun Dr. Mahathir Mohamad managed his administration well, a large number of respondents disapproved of the administration of $\mathrm{PH}$ as a whole. It was surmised that Tun Dr. Mahathir Mohamad may be a good leader but surrounded by inexperienced administration. This depiction directly led to the perception of the respondents especially when he offered resignation as the seventh PM. More than half of respondents (62.5\%) (Table 2) approved of his decision to resign from the highest executive position.

This might be due to the idea that even having a good leader, but with no solid management team, a leader could also be tarnished with negative reviews and performances. Despite the majority of them were having this hopeful sense over the new government with a percentage of 56.8\% (Table 3), most of the respondents were not proud of Tun Dr. Mahathir Mohamad during his stint in PH.

To summarise, Tun Dr. Mahathir Mohamad could be considered as irrelevant in today's political scene, based on the kind of setback, and downfall of PH. Strangely, 85.2\% of the respondents perceived that Tun Dr. Mahathir Mohamad worked well only during the BN government. Accordingly, Tun Dr. Mahathir Mohamad was a great leader, and with a good and solid team of BN, it could act as a catalyst for his performance (Table 4).

Table 2. Frequency distribution of Approval of Tun Dr. Mahathir Mohamad's Resignation.

\begin{tabular}{lcc}
\hline & Frequency & Percentage $(\boldsymbol{\%})$ \\
\hline Yes & 55 & 62.5 \\
No & 18 & 20.5 \\
Maybe & 15 & 17.0 \\
\hline Total & 88 & 100 \\
\hline
\end{tabular}

Table 3. Frequency distribution o Approval of Tun Dr. Mahathir Mohamad's Management in PH.

\begin{tabular}{lcc}
\hline & Frequency & Percentage (\%) \\
\hline Approve & 33 & 37.5 \\
Disapprove & 22 & 25.0 \\
Neutral & 33 & 37.5 \\
\hline Total & 88 & 100 \\
\hline
\end{tabular}

Table 4. Frequency distribution of approval of $\mathrm{PH}$ management.

\begin{tabular}{lcc}
\hline & Frequency & Percentage (\%) \\
\hline Approve & 18 & 20.5 \\
Disapprove & 48 & 54.5 \\
Neutral & 22 & 35.0 \\
\hline Total & 88 & 100 \\
\hline
\end{tabular}




\section{IMPLICATIONS AND CONCLUSION}

Tun Dr. Mahathir Mohamad and his administration were conceived negatively by the Malays as many of the concerns that were raised from their predecessor still continued to exist. They also have crashed the hopes and expectations of the people by not fulfilling their promises. For this, Tun Dr. Mahathir Mohamad could be considered as irrelevant in today's political scene, due to the setback experienced by his PH administration. As such, a staggering $85.2 \%$ of the respondent perceived that Tun Dr. Mahathir Mohamad worked well only during the BN government. Tun Dr. Mahathir Mohamad was himself a great leader, and with a good and solid team of $\mathrm{BN}$, it could act as a catalyst for his performance. These premises could have sparked as one of the major factors that led to the sudden change of government from PH to PN (Perikatan Nasional) through the 'Sheraton Move'.

All in all, the changes happening in our political scene are still a new thing that all Malaysians need to digest after being ruled with the same government for decades. Therefore, each Malaysian must be aware of current political issues happening daily for us to be equipped of what is yet to come. There must have a way to construct criticisms to provide check and balance but at the same time, criticisms must be tempered with a rational thought.

This study suggests that the return of Tun Dr. Mahathir Mohamad into Malaysia's political scene was not well accepted by the Malays in West Malaysia. The respondents believed that Tun Dr. Mahathir Mohamad worked best during his reign as PM under the BN banner. This study also proved that to govern a country is not all about the leader, but the systematic and holistic administration as a whole, needs to be taken into consideration. From this study as well, the emerging PH government has crashed the hopes and expectations mandated by the people. To develop further, they should not only rely on the power of an experienced leader such as Tun Dr. Mahathir Mohamad, but they also need to strive further to equip them with what is required to govern a country.

\section{REFERENCES}

Besar, J. A. (2019). Political change in the 14th general election (GE), 2018 in Malaysia. Geografia-Malaysian Journal of Society \& Space, 15(4), 220-232

Mohamed B. A. (2008). Lima puluh tahun dominasi Barisan Nasional dalam politik Malaysia: suatu analisis. Dalam Prosiding Seminar Politik Malaysia Landskap Politik Malaysia Pasca Pilihan Raya Ke-12. Shah Alam, MY.

Mohamed Noor, M. N., \& Jamaie, H. H. (2018). Politics, electorates and the malay/bumiputera's factor: an analysis on the failure of Barisan Nasional in the 2018 general election. Jebat-Malaysian Journal of History Politics and Strategic Studies, 45(2), 386-408

Mohamed Noor, M. N. (2018). The 14th General Election, the Fall of Barisan Nasional, and Political Development in Malaysia, 1957-2018. Journal of Current Southeast Asian Affairs, 37(3), 139-171. DOI: https://doi.org/10.1177/186810341803700307

Moniruzzaman, M., \& Farzana, K. F. (2018). Malaysia's 14th General Election: End of an epoch, and beginning of a new? Intellectual Discourse, 26(1), 207-228

Washida, H. (2018). Distributive Politics in Malaysia: Maintaining Authoritarian Party Dominance. In Distributive Politics in Malaysia: Maintaining Authoritarian Party Dominance. Routledge 